\title{
Relationship Between Equality Policies and Moral Legitimacy According to Experts' Perceptions
}

\author{
Alicia Blanco-González \\ Rey Juan Carlos University (Spain) \\ Giorgia Miotto \\ Ramon Llull University (Spain) \\ Francisco Díez-Martín \\ Rey Juan Carlos University (Spain) \\ Camilo Prado-Román \\ Rey Juan Carlos University (Spain)
}

The gender equality topic is gaining momentum both in the organizational and in the institutional management field. In order to close the gender gap that is common in the business environment, governments are promoting full and effective inclusion of women in all business areas and levels, developing useful policies to reach equal career progress opportunities and access to the highest level of the decision-making stages in the political, economic and public context. Companies also apply and implement these kinds of policies. The design and application of gender equality policies generates multiple benefits for companies' intangible assets, such as positive reputation and legitimacy. Companies who apply effective equality policies can expect an improvement in their internal and external social acceptance, and, therefore, an increase in their moral legitimacy perception. The objective of this study is to verify how gender equality policies influence the corporate moral legitimacy. To measure this relationship, a sample of 75 experts in social responsibility has been used and a model of a regression has been applied to measure the impact of gender equality policies on moral legitimacy.

Keywords: legitimacy, gender equality, corporate social responsibility, sustainability, ethics. for improving a better and more equal world. These strategies and policies are managed under the Corporate Social Responsibility (CSR) and 
Sustainability umbrella. However, there is still much to investigate about the organizational results of gender equality management. In this research we focus on the relationship between gender equality and organizational legitimacy.

Recently, the World Economic Forum published the Global Gender Report 2017, stating that, despite the fact that women represent half of the world's population, they do not have access to the same level of health assistance, education, economic participation, potential earning and political decision-making power (Bruggeman and Chan, 2016). Worldwide, the "Economic Participation and Opportunity gap" has been closed just up to the $58 \%$, stressing the great differences that gender still makes in the potential achievement of wealth and happiness (Schwab et al., 2017). More than 100 countries have taken action to track budget allocations for gender equality (United Nations, 2019).

Through the publishing of the Sustainable Development Goals, the United Nations made a strong call to action to all kind of companies in order to foster the accomplishment of the Sustainable Agenda 2030. Goal 5 is dedicated to promote Gender Equality to “Ensure women's full and effective participation and equal opportunities for leadership at all levels of decision-making in political, economic and public life and to adopt and strengthen sound policies and enforceable legislation for the promotion of gender equality and the empowerment of all women and girls at all levels" (United Nations, 2019). Gender Equality is an important dimension of the corporate ethics, affecting directly the decision-making process and the corporate governance at a whole, being related with transparency, accountability, fair opportunities for human personal and professional development and, finally, economic profitability (Cucari, Esposito de Falco, and Orlando, 2018; Harjoto, Laksmana, and Lee, 2015).

Company legitimacy derives from the recognition of its positive impact and is very important for the survival of organizations, because it ensures the flow of necessary resources to feed their activities (Baumann-Pauly, Scherer, and Palazzo, 2016; Patriotta, Gond, and Schultz, 2011). According with institutional theory, an organization acquires legitimacy when it operates in an appropriate, desirable and acceptable manner for the social system (Suchman, 1995). Therefore, it achieves the social acceptance, because it conforms with the values, rules and meanings of the system (Deephouse et al., 2017). Through Sustainability Reports organizations voluntary communicate their values and impacts to the economic, social and environmentally sustainable development and they are an important communication and legitimation tool (Hartman, Rubin, and Dhanda, 2007; Kolk, 2010; Kozlowski, Searcy, and Bardecki, 2015).

Moral legitimacy refers to perceptions linked to organizations' fairness, justice and impartiality (Galaskiewicz, 1985; Díez-Martín, Blanco-González, and Prado-Román, 2020, 2019). This type of legitimacy measures moral and ethical behavior. Hence, it is closely related to the fulfillment of social responsibility policies and the objectives of sustainable development (Díez-Martín, Blanco-González, and Prado-Román, 2019).

The majority of the academic literature related to this topic is focused on women's inclusion into boards or executive teams (Furlotti et al., 2019; Setó-Pamies, 2015). 
This research's objective is to analyze the relationship between equality policies and moral legitimacy according to experts' perceptions. This research is aimed to contribute to organizational behavior, sustainability and business ethics literature. Actually, nowadays, gender equality is considered an important ethic value for companies, which could use gender equality policies as a tool for legitimacy and sustained competitive advantage.

First, we present a literature review about the relationship between organizational legitimacy and gender equality, and, accordingly, we formulate our hypothesis. Secondly, we describe the sample and the methodology: 75 experts in social responsibility who grade the CSR policies of different multinational companies of the telecommunications, financial and energy industry. And thirdly, we present the main results and the implications of the study.

\section{LEGITIMACY AND GENDER EQUALITY}

Researchers suggest that when an organization carries out activities considered appropriate and ethical by the society: they increase the probability of attracting new customers (Kishna et al., 2017); they are more capable to convince potential costumers (Bojovic, Genet, and Sabatier, 2018); and they improve their performance (Wang, Song, and Zhao, 2014)a new venture must rely on early customers of its products to communicate value and commitment to others. For this reason, founders of new ventures focus more on early customers as a key element of their founding strategy than on other elements. But when do early customers really add value to new ventures? Scholars have used legitimacy theory to examine the benefits of gaining acceptance and conveying firm quality through conforming to social norms and following similar methods and forms. It has been argued that, independent of the customers of products and services, observable legitimacy characteristics of a new organization function as signals and are used by critical external constituents to infer the quality of the firm. This research, however, sheds little light on the manner in which firm legitimacy influences how potential customers respond to the existence of early customers. The current study therefore proposes that, depending on types of legitimacy (cognitive, regulative, and normative. Besides, legitimacy has a positive impact on the customer satisfaction (Kassinis and Soteriou, 2015), which drive to a favorable support, commitment and recommendation effect (Chaney, Lunardo, and Saintives, 2015).

However, we are living in a complex environment, where sometimes consumers behave inconsistently in their purchasing choices: they require easy access to all kinds of goods, but at the same time they expect brands to behave in an ethical, environmentally sustainable and socially responsible way (Iglesias et al., 2019)brands are facing an ever-increasing pressure to integrate ethical values into their identities and to display their ethical commitment at a corporate level. Nevertheless, studies that relate business ethics to corporate brands are either theoretical or have predominantly been developed empirically in goods contexts. This is surprising, because corporate brands are more relevant in services 
settings, given the nature of services (i.e., intangible, heterogeneous, inseparable and perishable. Attitudes and behaviors are often not coherent, and, even if consumers declare a preference for ethical brands, then their purchasing decisions do not always conform to these beliefs and values (Govind et al., 2017).

Despite this growing emphasis on social responsibility, the adoption of the Sustainable Development Goals' agenda, and the care for organizational legitimacy, few researches have been made to clarify this relationship. In this research, we analyze when, how and why equality policies influence the moral legitimacy of companies.

According to previous research (Furlotti et al.,, 2019; Galbreath, 2018) and the item included in the United Nations agenda for the sustainable development, the most important topics related to gender equality in the professional environment are:

- access to education

- equal opportunity in the career progress

- female employment

- gender salary gap

- sexual harassment protocol

- social programs addressed to women in the closest community

- working condition and health for female employees

- work-life balance

- women on board of directors

From a corporate point of view, the lack of gender equality is not only a problem of management and governance in all its dimensions and perspectives, but it can also cause a lack of legitimacy and it may negatively affect the perception and reputation of the brand (Miotto, Polo-López, and Rom-Rodríguez, 2019).

Organizational legitimacy is a widespread perception or assumption that the activities of an institutions are desirable, or appropriate within the defined socially constructive system of norms, values, beliefs, and definitions (Suchman, 1995). Legitimacy depends on the stakeholders' perception and is based on shared values and beliefs (Díez-Martín et al., 2014). Legitimacy depends on the ability to meet stakeholders' expectations, developing corporate, social, responsible and sustainable strategies and policies that provide credibility and trust to the organizations (Beddewela and Fairbrass, 2016; Díez-Martín, Prado-Román, and Blanco-González, 2013; Khurana and Nohria, 2008; Palazzo and Scherer, 2006).

Legitimacy is necessary to obtain the vital resources necessary to the organization survival (Zimmerman and Zeitz, 2002) Legitimacy improves the reputation of the company. Positive reputation increases legitimacy by providing brand awareness and trust (Deephouse et al., 2017). According to various investigations, CSR is a fundamental tool for legitimation (Porter and Kramer, 2011; Simcic-Brønn and Vidaver-Cohen, 2009) and, therefore, is a very important sustained competitive advantage (Furlotti et al., 2019), since CSR contributes to improving the companies' financial, reducing costs and risks (Orlitzky, Schmidt, and Rynes, 2003). 
Companies that develop policies that enhance equality and inclusivity, for example fostering women participation in the boards of directors, develop strategies based on social responsibility, business ethics and manage their stakeholders with higher profits and mutual benefits (Furlotti et al., 2019; Harjoto, Laksmana, and Lee, 2015). These positive impacts are all possible because these organizations behave ethically and responsibility (Galbreath, 2018).

When an organization dedicates resources to formulate specific strategies for obtaining or maintaining legitimacy, an overall assessment of organizational legitimacy is not enough. In these cases, it is necessary to investigate into the origin of the common and general judgment and understand more clearly the underlying motivation and the most significant aspects of stakeholders' perception. There are different typologies of legitimacy based on the origin of each organization legitimacy strategies and stakeholders' perceptions (Díez-de-Castro, Peris-Ortiz, and Díez-Martín, 2018). Each typology seeks to identify the different actors' assessment on a specific aspect of the legitimacy. These typologies differ from each other depending on the approach taken by the assessor to make the judgment.

At this stage we ask ourselves: how do organizations' equality policies influence the moral legitimacy?

Moral legitimacy is closely linked to the perceptions of fairness, justice, and impartiality about the actions of an organization. From a moral or ethical perspective, a legitimate organization, in order to achieve its objective, behaves according with values, actions, policies and procedures consistently with the stakeholders' needs and demands (Galaskiewicz, 1985). This evaluation approach is based on the judgments over the moral correctness of the organizations' activities, beyond the result obtained with those activities (Suchman, 1995). Moral legitimacy is achieved because there is congruence between values, beliefs and ethical thinking of the society, with the culture and the actions of the organization.

Likewise, this organizational behavior reflects the conformity of the actions with the legal framework and standards established by the authorities (Baum and Oliver, 1991; Deephouse, 1996). Organizations obtain legitimacy when they comply with the laws and regulations established by government's authorities and the public or private agencies to which they are associated. If an organization does not scrupulously comply with the laws, it will not obtain legitimacy.

Therefore, we formulate the following hypothesis:

Hypothesis 1. The development of equality policies increases the moral legitimacy of companies.

\section{SAMPLE AND METHODOLOGY}

The sample is represented by 75 experts in social responsibility who analyzed the Social Responsibility Reports of 13 multinational companies operating in Europe and Latin America in the telecommunications, energy and financial industry. They all meet international standards criteria related to social responsibility and 
environmental sustainability. We chose these three industries because they are traditionally masculinized sectors, and these industries are characterized by a high level of consumers complaints and dissatisfaction.

In this research we took into consideration the opinion of a set of experts about the CSR policies and actions reported by a set of companies in their Sustainability Reports. 75 experts were selected from different Spanish and universities from Central and South America, according to their academic experience in social responsibility and fulfilling the following criteria:

1. More than five years of academic teaching and research experience;

2. Active participation in the past five years at conferences, seminars, and workshops at a national and international level;

3. Valuable and impactful publications in the field of human resource management; and

4. Participation as reviewers and editors in national and international scientific journals.

All the experts have to own PhD degree. Research has shown the usefulness of the panel of experts (Okoli and Pawlowski, 2004). The objective was defined and described in the email and questionnaire sent to the experts so they would clearly understand the goal of this research. Experts based their evaluation on the Sustainability Reports published by the companies, the public financial and legal data and the information available online and in the media. This kind of assessment is common in research projects about CSR and legitimacy (Bansal and Clelland 2004; Deephouse et al., 2017)

We send the questionnaire and the Social Report of Multinational Company. The questionnaire was developed in 2 parts that conform to the policies and practices obtained from the CSR reports and main international standards (GRI and ISO 26000) and corporate legitimacy. The survey items are mentioned in Table 1 and they are based on an 11 points scale. The assessments refer to the years 2015, 2016, 2017 and 2018.

\section{RESULTS}

\section{Descriptive ANalysis}

First, the descriptive analysis was carried out in order to understand the values of gender equality policies and legitimacy assessed by the sample. Table 1 presents the results, showing the different factors as well as their items with their standard deviation obtained through the analysis of the survey's results. Regarding to gender equality policies, we see that not all of them achieve desirable values and positive evaluations. The analyzed companies obtain undesirable evaluations for the policies IG01 (Equal opportunities for professional development) and IG06 (Women on management positions). The better evaluated policies are IG08 (Social actions for women's communities - Participation) and IG04 (Female 
employment rate); that is, those policies with a more quantitative and objective measurement and affected by a system based on quotas.

Table 1. Descriptive Analysis

\begin{tabular}{|c|c|c|}
\hline ITEM & Mean & $\begin{array}{l}\text { Standard } \\
\text { Deviation }\end{array}$ \\
\hline IG01. Equal opportunities for professional development & 3.41 & 1.64 \\
\hline IG02. Salary gap & 5.61 & 1.52 \\
\hline IG03. Work-life balance & 6.19 & 1.26 \\
\hline IG04. Female employment rate & 7.80 & 1.58 \\
\hline IG05. Women health and working conditions & 6.75 & 1.52 \\
\hline IG06. Women on management positions & 3.15 & 2.24 \\
\hline IG07. Information about changes in organization to equal opportunities & 6.57 & 1.68 \\
\hline IG08. Social actions for women's communities - Participation & 7.98 & 1.67 \\
\hline IG09.Social actions for women's communities - Funding & 6.66 & 1.65 \\
\hline LM01. Maintains transparent relations with public institutions & 5.31 & 1.71 \\
\hline LM02. Contributions to political organizations are transparent & 3.94 & 1.93 \\
\hline LM03. Defend free competition and non-use of monopolistic practices & 5.91 & 1.94 \\
\hline LM04. Your economic-financial information is transparent & 7.89 & 1.46 \\
\hline LM05. Does not collaborate with suppliers that evade taxes & 6.54 & 1.95 \\
\hline LM06. Have programs and / or use sustainable technologies & 9.12 & 1.29 \\
\hline LM07. Promotes respect for international treaties and standards & 8.58 & 1.11 \\
\hline LM08. Protect human rights & 6.80 & 2.16 \\
\hline LM09. Look for customer satisfaction and listen to their suggestions and requirements & 8.79 & 1.16 \\
\hline LM10. Promote ethical and / or social values in your campaigns & 6.70 & 1.46 \\
\hline $\begin{array}{l}\text { LM11. Reject non-loyal marketing, which violates consumer privacy or morally } \\
\text { abusive }\end{array}$ & 5.42 & 1.82 \\
\hline $\begin{array}{l}\text { LM12. There are specific and explicit rules and / or codes of ethical conduct defined by the } \\
\text { company }\end{array}$ & 9.42 & 1.21 \\
\hline LM13. Direct part of the sales revenue of certain products to social programs & 6.36 & 1.50 \\
\hline LM14. Collaborate with social organizations & 7.28 & 1.87 \\
\hline
\end{tabular}

The values of moral legitimacy indicate that companies must improve in LM2 (Contributions to political organizations are transparent) and that they are committed with LM6 (Have programs and / or use sustainable technologies) and 
110 LM12 (There are specific and explicit rules and / or codes of ethical conduct defined by the company).

\section{Causal Analysis}

Considering the descriptive analysis and in order to verify the influence of equality policies on the companies' legitimacy, an Exploratory Factor Analysis is carried out on the variable of moral legitimacy. We therefore applied a construct of variables that measures global moral legitimacy. The construction of this new variable exceeded the precise statistical indicators (Cronbach Alpha $=0.932$; Variance extracted $=0.53$; and Variance by item $>0.50$ ).

Following, we performed a regression in which the dependent variable is legitimacy and the independent variables are each one of the equality policies (Table 2). The results confirm that there is a direct and positive relationship between these policies and legitimacy, since 54\% of the relationship is confirmed. However, not all equality policies influence legitimacy.

\section{Table 2. Regression Analysis}

\begin{tabular}{|c|c|c|}
\hline ITEM & Beta & T -Value \\
\hline IG01. Equal opportunities for professional development & 0.111 & 1.54 \\
\hline IG02. Salary gap & 0.017 & 0.18 \\
\hline IG03. Work-life balance & $0.174^{\star * \star}$ & 1.99 \\
\hline IG04. Female employment rate & $0.212^{\star * *}$ & 2.40 \\
\hline IG05. Women health and working conditions & -0.003 & -0.03 \\
\hline IG06. Women on management positions & $0.141^{* * *}$ & 1.97 \\
\hline IG07. Information about changes in organization to equal opportunities & $0.245^{* * *}$ & 3.15 \\
\hline IG08. Social actions for women's communities - Participation & 0.113 & 1.48 \\
\hline IG09. Social actions for women's communities - Funding & $0.195^{\star * \star}$ & 2.49 \\
\hline $\begin{array}{l}\text { Moral Legitimacy: } \mathrm{R}^{2}=0.54 \\
{ }^{* \star} \mathrm{p}<0.001 ;{ }^{* \star} \mathrm{p}<0.01 ;{ }^{*} \mathrm{p}<0.05\end{array}$ & & \\
\hline
\end{tabular}

Policies with a significant and positive influence on legitimacy are: IG03 (Worklife balance), IG04 (Female employment rate), IG06 (Women on management positions) y IG07 (Information about changes in organization to equal opportunities). Nevertheless, these policies do not influence legitimacy perception: IG01 (Equal opportunities for professional development), IG02 (Salary gap), IG05 (Women health and working conditions) y IG08 (Social actions for women's communities - Participation).

These results point out that the strategies that better work for maintaining corporate legitimacy are the ones that are linked to the company's communi- 
cation strategies and efforts. As we explain in the implications' chapter, it is

interesting to identify that the policies with a higher influence on legitimacy are those related to public aspects and external communication, and not the ones linked to real business model and management changes addressed to obtain and foster gender equality.

\section{IMPLICATIONS}

Nowadays organizations are scrutinized by all the stakeholders and the society is very demanding in term of equality policies. Gender equality is the main topic of the UN SDG 5, which establishes that one of the 2030 Sustainable Agenda's priority is to reduce the gender gap (United Nations, 2019).

Companies are required not only to obtain economic benefits, but also to be responsible for their actions in front of the society and behave ethically and morally. Organizations must get involved with their stakeholders, promoting inclusiveness and equality.

In this scenario, the organizations are aware that new factors affect their decision-making process and new variables that were not previously considered have gained prominence in management. Intangible assets management is one of the most important issues in all kind of organizations (Castillo-Feito, Blanco-González, and Delgado-Alemany, 2019; Miotto, Castillo-Feito, and Blanco-González, 2020). Within these intangible assets, we include the organizational legitimacy that refers to social acceptance (Suchman, 1995) and which is a key factor to ensure the survival of the companies, the stakeholders' support and the resources availability (Díez-Martín et al., 2014).

Moral legitimacy refers to the perceptions of fairness, justice and impartiality about organizations' actions (Galaskiewicz, 1985). It is deeply linked to the fulfillment of social responsibility policies and of the objectives of sustainable development. For this reason, we chose to collect the opinion of 75 experts in social responsibility about the policies implemented by a set of companies those operate in traditionally gender-dominated sectors. Through the experts' assessment, we quantified and measured whether equality policies influence legitimacy or not.

Firstly, the results indicate that, several times, gender equality policies are not adequately implemented. Companies should improve on "Equal opportunities for professional development" and on inclusion of more "Women on management positions". At the same time, companies obtain a good evaluation for their "Social actions for women's communities - Participation" and "Female employment rate".

Second, the disaggregated analysis of moral legitimacy indicates that companies should improve their commitment with transparency and accountability. At the other hand, companies obtain good results in the implementation of "programs and / or use of sustainable technologies" and in the implementation and definition of "specific and explicit rules and / or codes of ethical conduct".

Third, the results of the regression analysis allow us to validate the research's hypothesis: The development of equality policies increases companies' moral legitima- 
$c y$, and with it, their ethical commitment towards the achievement of the UN Sustainable Development Goals 5.

The research results show several differences between legitimacy - linked effective and not effective policies.

The gender equality policies those influence legitimacy are: "Female employment rate", "Women on management positions", "Information about equal opportunities", and "Social actions for women's communities and Projects Funding". These policies are related to the companies' communication strategies and external marketing strategies, with a high impact and exposure on the media.

On the contrary, the gender equality policies that do not influence legitimacy are: "Equal opportunities for professional development", "Salary gap", "Women health and working conditions", and "Social actions for women's communities Participation". All these policies determine a deep organizational change, the involvement of the stakeholders and a deep internal change in the business model, management style and decision-making process.

Considering these results and considerations, we determine that companies are aware of the influence of gender equality policies on legitimacy and of the importance of meeting and fostering the UN SDG5 in order to improve their legitimacy. We also determine that, according to the theory of the intangible assets management, companies have focused on those policies with the greatest impact and coverage on the media. Nevertheless, we consider that companies should go one step further and implement organizational changes that lead to real and consistent gender equality, not only to obtain good publicity and an improvement of the positive reputation through a well-managed communication strategy. They should not only focus on equality policies to achieve isomorphism (Díez-Martín et al., 2014), they should develop gender equality strategies that change deeply the organizational structures and mindset. They should understand that, through inclusiveness and equality they will increase their legitimacy and, therefore, obtain a sustained competitive advantage (Miotto, Castillo-Feito, and Blanco-González, 2019).

Finally, we are aware of the limitations of this study, since we just took into consideration multinational companies from a set of specific industries. This lack of plurality in the sample encourages future researchers to investigate and compare the results with other sectors, to carry out longitudinal studies to check the degree of implementation of the policies, or to analyze different stakeholders' opinions about the degree of compliance with the SDG 5 and the efficiency and effectiveness of the companies' equality policies to close the gender gap.

Alicia Blanco-González (alicia.blanco@urjc. es) received her PhD in 2009 from Rey Juan Carlos University. She is an Associate Professor in Business Economics Department at Rey Juan Carlos University (Madrid) and ViceDean of Academic and International Affairs. Alicia is Vice-President of European Academy of Management and Business Economics and member of Spanish Association of Academic and Professional Marketing. She is Secretary General of the Camilo Prado Foundation. Her research interests include organizational legitimacy, reputation, social responsibility and consumer behavior. 
Giorgia Miotto (giorgiam@blanquerna.url.edu) is Associate Professor of the School of Communication and International Relations Blanquerna - Ramon Llull University and Vice-Dean for Corporate Relationship and Innovation. She holds a PhD in Advanced Communication from the Ramon Llull University (URL), focusing her research in the relation-

pact) and of PRME (Principle for Responsible Management Educations - United Nations).

Francisco Díez-Martín (francisco.diez@urjc. es) received his PhD in 2007 from Seville University. He is an Associate Professor in the Business Economics Department at Rey Juan Carlos University (Madrid). Francisco is a member of

Camilo Prado-Román (camilo.prado.roman@ urjc.es). Associate Professor of Finance at Rey Juan Carlos University. Secretary-General of the European Academy of Management and Business Economics (AEDEM). Patron of the Fundación Camilo Prado. PhD in finance and business economics (Rey Juan Carlos University). International Program in Corporate Social ship between corporate legitimacy, CSR strategy and communication. She has an Executive MBA from EADA Business School. Giorgia is a former member of the Executive Committee of the Red Española del Pacto Mundial de Naciones Unidas (Spanish Network of the United Nations Global Compact - UN Global Com-

the European Academy of Management and Business Administration. He is also Director for the Master in Advanced Management (Rey Juan Carlos University). He is editor of Journal of Management and Business Education (JMBE). His research interests include organizational legitimacy and institutional theory.

Responsibility (University of Buenos Aires). Specialist in Quantitative Research Methodology and Statistical Techniques (Technical University of Madrid). Specialist in Alternative Investment (Rey Juan Carlos University). Bachelor of Business Administration (University College of Financial Studies - CUNEF - attached to Complutense University of Madrid-UCM).

\section{References}

Bansal, Pratima and Clelland, Iain (2004). "Talking Trash: Legitimacy, Impression Management, and Unsystematic Risk in the Context of the Natural Environment". Academy of Management Journal, 47(1), pp. 93-103.

Baum, Joel A. C. and Oliver, Christine (1991). "Institutional Linkages and Organizational Mortality". Administrative Science Quarterly, 36(2), pp. 187-218.

Baumann-Pauly, Dorothee; Scherer, Andreas George, and Palazzo, Guido (2016). "Managing Institutional Complexity: A Longitudinal Study of
Legitimacy Strategies at a Sportswear Brand Company". Journal of Business Ethics, 137, pp. 31-51.

Beddewela, Eshani and Fairbrass, Jenny (2016). "Seeking Legitimacy Through CSR: Institutional Pressures and Corporate Responses of Multinationals in Sri Lanka". Journal of Business Ethics, 136(3), pp. 503-522.

Bojovic, Neva; Genet, Corinne, and Sabatier, Valerie (2017). "Learning, Signaling, and Convincing: The Role of Experimentation in the Business Modeling Process". Long Range Planning, 51(1), pp. 141-157. 
Bruggeman, Paula and Chan, Hillary (2016). "Minding the Gap: Tapping the Potential of Women to Transform Business". Available at: <https://www.gmac.com/marketintelligence-and-research/research-library/ diversity-enrollment/rr-16-01-minding-thegap>. Accessed 1 April 2020.

Castillo-Feito, Cristina del; Blanco-González, Alicia, and Delgado-Alemany, Rafael (2020). "The Relationship Between Image, Legitimacy, and Reputation as a Sustainable Strategy: Students' Versus Professors' Perceptions in the Higher Education Sector". Sustainability, 12(3), pp. 1189-1195.

Chaney, Damien; Lunardo, Renau, and Saintives, Camille (2015). "In-Store Quality (in)Congruency As a Driver of Perceived Legitimacy and Shopping Behavior". Journal of Retailing and Consumer Services, 24, pp. 51-59.

Cucari, Nicola; Esposito de Falco, Salvatore, and Orlando, Beatrice (2018). "Diversity of Board of Directors and Environmental Social Governance: Evidence from Italian Listed Companies". Corporate Social Responsibility and Environmental Management, 25(3), pp. 250266. Available at: <https://doi.org/10.1002/ csr.1452>

Deephouse, David L. (1996). "Does Isomorphism Legitimate?" Academy of Management Journal, 39(4), pp. 1024-1039.

Deephouse, David L.; Bundy, Jonathan; Tost, Leigh Plunkett, and Suchman, Marc C. (2017). “Organizational Legitimacy: Six Key Questions". In: Greenwood, R.; Oliver, C.; Lawrence, T., and Meyer, R. (eds.). The SAGE Handbook of Organizational Institutionalism. 2nd ed. Thousand Oaks CA: Sage, pp. 28-54.

Díez-de-Castro, Emilio; Peris-Ortiz, Marta, and Díez-Martín, Francisco (2018). "Criteria for Evaluating the Organizational Legitimacy: A Typology for Legitimacy Jungle". In: Díezde-Castro, E. and Peris-Ortiz, M. (eds.). Organizational Legitimacy. Cham: Springer International Publishing, pp. 1-21.

Díez-Martín, Francisco; Blanco-González, Alicia, and Prado-Román, Camilo (2019).
"Factors Affecting Individual Decisions Based on Business Legitimacy". Journal of Promotion Management, 25(2), pp. 181-199.

—. (2020). "The Intellectual Structure of Organizational Legitimacy Research: A Co-Citation Analysis in Business Journals". Review of Managerial Science, pp. 1-37. Available at: <https://doi. org/10.1007/s11846-020-00380-6>.

Díez-Martín, Francisco; Blanco-González, Alicia; Cruz-Suárez, Ana, and Prado-Román, Camilo (2014). "Efecto de la responsabilidad social empresarial sobre la legitimidad de las empresas". Anuario Jurídico y Económico Esculiarense, (XLVII), pp. 325-348.

Díez-Martín, Francisco; Prado-Román, Camilo, and Blanco-González, Alicia (2013). "Beyond Legitimacy: Legitimacy Types and Organizational Success". Management Decision, 51(10), pp. 1954-1969.

Furlotti, Katia; Mazza, Tatiana; Tibiletti, Veronica, and Triani, Silvia (2019). "Women in Top Positions on Boards of Directors: Gender Policies Disclosed in Italian Sustainability Reporting". Corporate Social Responsibility and Environmental Management, 26(1), pp. 57-70.

Galaskiewicz, Joseph (1985). "Interorganizational Relations". Annual Review of Sociology, 11(1), pp. 281-304.

Galbreath, Jeremy (2018). "Is Board Gender Diversity Linked to Financial Performance? The Mediating Mechanism of CSR". Business \& Society, 57(5), pp. 863-889.

Govind, Rahul; Singh, Jatinder Jit; Garg, Nitika, and D'Silva, Shachi (2019). "Not Walking the Walk: How Dual Attitudes Influence Behavioral Outcomes in Ethical Consumption". Journal of Business Ethics, 155(4), pp. 1195-1214.

Harjoto, Maretno; Laksmana, Indrarini, and Lee, Robert (2015). "Board Diversity and Corporate Social Responsibility". Journal of Business Ethics, 132(4), pp. 641-660.

Hartman, Laura P.; Rubin, Robert S., and Dhanda, K. Kathy (2007). "The Communication of Corporate Social Responsibility: United States and European Union Multinational 
Corporations". Journal of Business Ethics, 74, pp. 373-389.

Iglesias, Oriol; Markovic, Stefan; Singh, Jatinder Jit, and Sierra, Vicenta (2019). “Do Customer Perceptions of Corporate Services Brand Ethicality Improve Brand Equity? Considering the Roles of Brand Heritage, Brand Image, and Recognition Benefits". Journal of Business Ethics, 154(2), pp. 441-459.

Kassinis, George I. and Soteriou, Andreas C. (2015). "Environmental and Quality Practices: Using a Video Method to Explore Their Relationship with Customer Satisfaction in the Hotel Industry". Operations Management Research, 8(3-4), pp. 142-156.

Kishna, Maikel; Niesten, Eva; Negro, Simona, and Hekkert, Marko P. (2017). "The Role of Alliances in Creating Legitimacy of Sustainable Technologies: A Study on the Field of Bio-plastics". Journal of Cleaner Production, 2(1), pp. 7-16.

Kolk, Ans (2010). "Multinationals and Corporate Social Responsibility". Politeia, 26(98), pp. $138-152$

Kozlowski, Anika; Searcy, Cory, and Bardecki, Michal (2015). "Corporate Sustainability Reporting in the Apparel Industry: An Analysis of Indicators Disclosed". International Journal of Productivity and Performance Management, 64(3), pp. 377-397.

Khurana, Rakesh and Nohria, Nitin (2008). "It's Time To Make Management a True Profession". Harvard Business Review, 86(10), pp. 70-77.

Miotto, Giorgia; Polo-López, Marc, and Rom-Rodríguez, Josep (2019). "Gender Equality and UN Sustainable Development Goals: Priorities and Correlations in the Top Business Schools' Communication and Legitimation Strategies". Sustainability, 11 (2), pp. 302.

Miotto, Giorgia; Castillo-Feito, Cristina del, and Blanco-González, Alicia (2020). "Reputation and Legitimacy: Key Factors for Higher Education Institutions' Sustained Competitive Advantage". Journal of Business Research, 112 (June), pp. 342-353. Available at: <https:// doi.org/10.1016/j.jbusres.2019.11.076>
Okoli, Chitu and Pawlowski, Suzanne D. (2004). "The Delphi Method As a Research Tool: An Example, Design Considerations and Applications". Information \& Management, 42(1), pp. 15-29.

Orlitzky, Marc; Schmidt, Frank L., and Rynes, Sara L. (2003). "Corporate Social and Financial Performance: A Meta-analysis". Organizational Studies, 24(3), pp. 403-441.

Palazzo, Guido, and Scherer, Andreas George (2006). "Corporate Legitimacy As Deliberation: A Communicative Framework". Journal of Business Ethics, 66(1), pp. 71-88.

Patriotta, Gerardo; Gond, Jeanne Pascal, and Schultz, Frederike (2011). "Maintaining Legitimacy: Controversies, Orders of Worth, and Public Justifications". Journal of Management Studies, 48(8), pp. 1804-1836.

Porter, Michael E. and Kramer, Mark R. (2011). "Creating Shared Value". Harvard Business Review, 89(1-2), pp. 1-17.

Schwab, Klauss (2017). "The Fourth Industrial Revolution: What it Means, How To Respond". Available at <https://professionallearning.education.gov.scot/media/1352/thefourth-industrial-revolution-what-it-meansand-how-to-respond-world-economic-forum. pdf>. Accessed 1 April 2020.

Schwab, Klaus; Smans, Richard; Zahidi, Saadia; Leopold, Till Alexander; Ratcheva, Vessellina; Haussman, Ricardo, and Tyson, Laura (2017). Insight Report: The Global Gender Gap Report 2017. Geneve. Retrieved from <http://www3.weforum.org/docs/WEF_ GGGR_2017.pdf>

Setó-Pamies, Dolors (2015). “The Relationship Between Women Directors and Corporate Social Responsibility". Corporate Social Responsibility and Environmental Management, 22(6), pp. 334-345.

Simcic-Brønn, Peggy and Vidaver-Cohen, Deborah (2009). "Corporate Motives for Social Initiative: Legitimacy, Sustainability, or the Bottom Line?" Journal of Business Ethics, 87(1), pp. 91-109. 
Suchman, Mark C. (1995). "Managing Legitimacy: Strategic and Institutional Approaches". Academy of Management Review, 20(3), pp. 571-610.

United Nations (2019). Sustainable Development Goal 5: Achieve Gender Equality and Empower All Women and Girls. New York. Retrieved from <https://sustainabledevelopment. un.org/sdg5>

Wang, Tang; Song, Michael, and Zhao, Y. Lisa (2014). "Legitimacy and the Value of
Early Customers". Journal of Product Innovation Management, 31(5), pp. 1057-1075.

World Economic Forum (2017). "Global Gender Report 2017". Avaible at: <https:// www.weforum.org/reports/the-globalgender-gap-report-2017>. Accessed 1 April 2020. Zimmerman, Monica A. and Zeitz, Gerald J. (2002). "Beyond Survival: Achieving New Venture Growth by Building legitimacy". Academy of Management Review, 27(3), pp. 414-431. 